\title{
Michael Lönz
}

\author{
Ruhr University Bochum, Germany
}

\section{COMMUNITY IN DIVERSITY. A PLEA OF A SUBSTANTIAL MULTILINGUALISM IN A COMMON EUROPE ${ }^{4}$}

\begin{abstract}
Summary. To understand Europe means to understand diversity, diversity in culture, political practice and also in language. But in the multilingual Europe multilingualism is threatened, e.g., by a predominant English. Therefore, the EU Commission is promoting "linguistic diversity". The paper discusses what could be meant with this term. First, it is necessary to say that monolingualism accompanied only the rising of the national state in the 19th and 20th century. Then the position of a lingua franca was questioned in the modern world, especially, in modern Europe, to defend finally the proposition that a decent society must provide not only social or political but also linguistic justice by developing a substantial mulitilingualism. This multilingualism must also give the minor languages the chance to be used by a wider audience. The paper ends with two demands for the development of substantial multilingualism: the demand for an obligation to teach at least three foreign languages to every pupil at every school and the demand for an obligation to teach at least some subjects in a foreign language at every school and this foreign language should not be exclusively English.
\end{abstract}

Keywords: Linguistic diversity, linguistic justice, multilingualism, lingua franca, minor languages.

\section{Introduction}

One word is sufficient to characterize Europe: difference. Europe is diverse in nation, legal system, tradition, religion, custom, and - naturally - in language. Europe is a multilingual continent. Ever since the beginning of "Europe" a multilingual experience has taken place. On 14 February 842, Louis the German, the ruler of East Francia, and his half-brother Charles the Bald, ruler of West Francia, pledged allegiance to the other in attendance of their assembled armies speaking the oath in the language of the respective other part of the former empire of Charlemagne, Louis in Old French, Charles in Old High German; and there was also a Latin version of the oath for future juridical use (cf. Lönz, 2012). But Europe is also a continent in search of community and understanding. Therefore, the problems of multilingualism have been on the European agenda since its coming into being, and it is not surprising that it is now on the agenda of the European Commission as well.

4 This article is a revised version of the paper presented at the international scientific conference "Sustainable Multilingualism: Research, Studies, Culture" at Vytautas Magnus University, Kaunas, on 27-28 September 2013 (translations without reference by the author). 
According to the Commission's 2005 New Framework Strategy for Multilingualism, "multilingualism refers to both, a person's ability to use several languages and the coexistence of different language communities in one geographical area" (Commission, 2005, p. 3). In this strategy the Commission defines three aims of its language policy:

- to encourage language learning and promoting linguistic diversity in society;

- to promote a healthy multilingual economy, and

- to give citizens access to European Union legislation, procedures and information in their own languages" (do.)

It appears to be basically clear what is meant by "to encourage language learning" and "to give citizens access to European Union legislation, procedures and information in their own languages", but there is a need of clarification concerning the terms "linguistic diversity in society" and "a healthy multilingual economy". Because of the preceding word "promoting" both expressions seem to be meant normative, as a justified aim of the Commissions policy. While the Framework Strategy speaks about the "contribution of language skills to the competitiveness of the EU economy" showing at least the beginnings of justification of the promotion of a multilingual economy, it lacks in any form of justifying the worth of linguistic diversity in society. And the 2008 Report Multilingualism: an asset for Europe and shared commitment the Commission does not really remedy this lack. But it considers that "each of the many national, regional, minority and migrant languages spoken in Europe adds a facet to our common cultural background. It should be shared to foster a dialogue and mutual respect." (Commission 2008, p. 5). This can be read as a first step towards justification of the worth of linguistic diversity in society. Below I will give some further remarks why we should and how we can promote it.

In view of the fact that we are usually said to be citizens of an essentially monolingual nation, my paper will

- first show that the monolingual nation is the outcome of a special historical situation,

- then discuss the position of a lingua franca in the modern world, especially in modern Europe,

- to defend finally the proposition that a decent society must provide not only social or political but also linguistic justice by developing a substantial multilingualism.

\section{The European societies on the way to monolingualism}

To understand today's European linguistic situation we have to go back to the end of the $18^{\text {th }}$ century. Before the age of enlightenment and revolution, the linguistic situation in Europe in general was like the political one: multidimensional diversity. People with contact to other people, not only foreigners, but also to people in their home towns, needed the competence to speak to another in different languages, and they had this knowledge (Tandefeldt, 2003). The situation changed when the people of France began to remove the ancien régime in the French Revolution. The first year of the Revolution saw members of the Third Estate in the états généraux proclaiming the Third Estate as the French nation and declaring the Rights of Man and of the Citizen. But what kind of thing was this French Nation? For sure not a French speaking nation! 
Only for less than $40 \%$ (that is the most accepted figure; in the relevant literature the figures differ from $10 \%$ up to $50 \%$ ) of the inhabitants of France at the end of the $18^{\text {th }}$ century French was the mother tongue and most of the remaining, more than $60 \%$, did not speak or even understand French (Lüdi, 2012, p. 211). The struggles about other major reforms in the following years were always an attempt to secure this Nation and the Rights of Man and of the Citizen.

This was also true on the $27^{\text {th }}$ of January 1794 when Bertrand Barère, member of the welfare committee of the national assembly, declared: «Laisser les citoyens dans l'ignorance de la langue nationale, c'est trahir la patrie ... la langue d'un peuple libre doit être une et la même pour tous. Dès que les hommes pensent, dès qu'ils peuvent coaliser leurs pensées, l'empire des prêtres, des despotes et des intrigants touche à sa ruine. Donnons donc aux citoyens l'instrument de la pensée publique, l'agent le plus sûr de la révolution, le même langage.» [Bertrand Barère de Vieuzac. Rapport du Comité de salut public sur les idiomes du 8 pluviôse an II (27 janvier 1794). Quoted in Certeau/Julia/Revel 1974 pp. 291-299)]. ${ }^{5}$ The welfare committee also proposed a law concerning the dissimilation of the French language in the whole Republic. This law ordered:

Article I

Il sera établi dans dix jours, à compter du jour de la publication du présent décret, un instituteur de langue française dans chaque commune de campagne des départements du Morbihan, du Finistère, des Côtes-du-Nord et dans la partie de la Loire-Inférieure dont les habitants parlent l'idiome appelé bas-breton.

\section{Article II}

Il sera procédé à la même nomination d'un instituteur de la langue française dans chaque commune des campagnes des départements du Haut et Bas-Rhin, dans le département de la Corse, dans la partie du département de la Moselle, du département du Nord, du Mont-Terrible, des Alpes maritimes, et de la partie des Basses-Pyrénées dont les habitants parlent un idiome étranger.

$\ldots$

Article IV

Les instituteurs seront tenus d'enseigner tous les jours la langue française et la Déclaration des droits de l'Homme à tous les jeunes citoyens des deux sexes que les pères, mères et tuteurs seront tenus d'envoyer dans les écoles publiques; les jours de décade ils donneront lecture au peuple et traduiront vocalement les lois de la république en préférant celles relatives à l'agriculture et aux droits des citoyens.» ${\text { (ibid. })^{6}}^{6}$

5 "Allowing citizens stay in ignorance of the national language, is to betray the country ... the language of a free people must be one and the same for all. When men begin to think, when they can unite their thoughts, the empire of the priests, despots and schemers will be ruined. So give citizens the instrument of public thought, the safest agent of the revolution, the same language."

6 Article I

In ten days from the date of publication of this decree, a teacher of French language will be appointed in every municipality of the départments of Morbihan, Finistère, Côtes -du-Nord and that part of the Loire-Inférieure, whose inhabitants speak the language called Breton. Article II

The same appointment of a teacher of the French language will take place in each municipality in départments of Haut and Bas-Rhin, in the départment of Corsica, in those parts of the départment of Moselle and départments of Nord, Mont- Terrible, the Alpes Maritimes, and part of the Bas-Pyrenées whose inhabitants speak a foreign language. Article IV

The teachers are required to teach every day the French language and the Declaration of Human Rights to all young people of both sexes, whose fathers, mothers or guardians are obliged to send them to the state schools; the day of the decade [equivalent to Sunday in the calendar of the revolution; M.L.] they will read and translate orally the laws of the Republic preferring those related to agriculture and the rights of citizens to the general public. " 
In the most non-French speaking parts of France, the use of the French language had to be carried through, and this immediately after the law had been passed: ten days after this bill had passed the National Assembly, teachers of French had to teach all the people, not only the pupils, the French language in every community, where the people spoke a foreign language. The mother tongue of those people was then declared a foreign language; the language divided between us and them, between the citoyens as part of the French nation and the outsiders not being part of this nation. The citoyen, however, was no longer a subject of a higher authority, a subject of a king or God, he himself was the authority. Therefore, the teachers were obliged not only to teach French but also to teach the Rights of Man and of the Citizen. If you speak French so that you are not a foreigner anymore you are part of the nation and fulfill the qualification of being a citoyen covered by the Rights of Man and of the Citizen. The French nation is not "one nation under God" as the Americans define themselves, but a nation of free and self-governing citizens. You can hear it up to now in the conclusion of formal speeches of the French president; normally he is concluding "vive la république, vive la France", "long live the republic, long live France"; first, the community of citizens, citoyens, constituting, second, the nation and the national state. Monolingualism in this tradition is one of the believed foundational conditions of a nation of free men. ${ }^{7}$

But that is not the only root of modern monolingualism. A second root is paradigmatically expressed in the Эмский указ, the Ems ukaz of the Russian Tsar Alexander II.. While enjoying a spa in Bad Ems, Germany, in May 1876, the Tsar signed a (secret) law, an ukaz, extending the yet existing publication ban to be applied to all books and song lyrics in the Ukrainian language, that is not even named correctly as Украинский язык, the Ukrainian language, but addressed as "малорусский наречии" "Little Russian dialect", and prohibiting the importation of such material. ${ }^{8}$ The first paragraphs address the minister of the interior:

1. Не допускать ввоза в пределы Империи, без особого на то разрешения Главного Управления по делам печати, каких бы то ни было книг, издаваемых за границей на малорусском наречии.

2. Воспретить в Империи печатание, на том же наречии, каких бы то ни было оригинальных произведений или переводов, за исключением исторических памятников, но с тем, чтобы и эти последние, если принадлежат к устной народной словесности (каковы песни, сказки, пословицы), издаваемы были без отступления от общерусской орфографии (то есть не печатались так называемой «кулишовкою»). ...

3. Воспретить равномерно всякие на том же наречии сценические представления, тексты к нотам и публичные чтения (как имеющие в настоящее время характер украинофильских манифестаций). .."9

In the second part the minister of education is the addressee:

a more extensive look in Brumme/Bochmann/Guespin 1993, pp. 63-100.

8 to learn more about the background cf. Magocsi, 1996, pp. 368-371, and Miller, 2003 pp. 179-246.

9 "1. To forbid the importation within in the imperial borders, without a the special permission of the Chief Directorate on Publications, of any books published abroad in the Little Russian dialect. 2. To prohibit the publication in that dialect within the empire of any original works or translations, with the exception of ancient texts - although these latter, if they belong to oral folk tradition (such as songs, fairy tales, proverbs), should also be published in accordance with All-Russian orthography (i.e., should not be published in the so-called kulishkova)... 3. To prohibit all stage performances, lyrics to music, and public readings (as they presently have the character of Ukrainophile manifestations)" (translation according to Miller, 2003, p. 267). 
6. Усилить надзор со стороны местнаго учебнаго начальства, чтобы не допускать в первоначальных училищах преподавания каких бы то ни было предметов на малорусском наречии.

7. Очистить библиотеки всех низших и средних училищ в малороссийских губерниях от книг и книжек, воспрещаемых 2-м параграфом настоящего проекта.

8. Обратить серьезное внимание на личный состав преподавателей в учебных округах Харьковском, Киевском и Одесском, потребовав от попечителей сих округов именного списка преподавателей с отметкою о благонадежности каждого по отношению к украинофильским тенденциям, и отмеченных неблагонадежными или сомнительными перевести в великорусские губернии, заменив уроженцами этих последних"10 (quoted in Miller 2003, pp. 270f.).

Similar laws, etc. can be named for other languages in the Russian empire. I took the Ems ukaz as an example not only, because it is the most "famous" of these laws, but it shows so well the character of this forced monolingualism. All eastSlavic languages are only inferior dialects of the Russian language symbolizing the naturalness of the Russian rule about the other east-Slavic tribes. And converting Tsar Peter's opening to the west, all non-east-Slavic languages are inferior to the east-Slavic ones as part of the legitimation of the Russian rule about the west-Slavic, Baltic, etc. people. The Soviet Union has continued this practice, at least since the Stalinist era (Smith, 2012) and in the context of Sovietization (Mertelsmann 2012a). I do not use the term "nation" here to reserve it for the "republican" version. That is to distinguish between these two strategies of carrying through the monolingualism.

Although they differ in nearly everything, these two developments, the "republican" in France or in the $19^{\text {th }}$ century Italy and the "imperialistic" in Russia, Prussia or Hungary have had and have the same end: the extinction of the mother tongues of many people, as did the national uprising in many parts of Europe in the $19^{\text {th }}$ and early $20^{\text {th }}$ century promoting a one and only national language as central for the constitution of the (new) nations.

But still in the $19^{\text {th }}$ century you can think about the (republican) nation in a way that avoids the extinction of languages among other things. Ernest Renan says in his famous speech "What is a nation?": A nation is grounded in «une grande solidarité, constituée par le sentiment des sacrifices qu'on a faits et de ceux qu'on est disposé à faire encore. Elle suppose un passé; elle se résume pourtant dans le présent par un fait tangible: le consentement, le désir clairement exprimé de continuer la vie commune» (Renan, 1882, p. 27) ${ }^{11}$. The will to live together in future is the founding document of a nation, not a common faith, a common history or a common language. The best example for this is, in my opinion, Switzerland where despite all real and

10 "6. To strengthen the control exercised by the local educational authorities so as not to allow in elementary school any instruction in the Little Russian dialect in elementary school, regardless of the subject.

7. To purge the libraries of all elementary and middle schools in the Little Russian guberniias of books and booklets prohibited by the second paragraph of the present project.

8. To pay serious attention to the teaching faculty in Kharkov, Kiev, and Odessa school districts, by demanding from the trustees of these districts to prepare lists withof the instructors' names with a comment regarding of each instructor's ones loyalty in respect to Ukrainophile tendencies; those marked as disloyal or suspect should be transferred to Great Russian guberniias and replaced by natives of these guberniias." (translation according to ibid., p. 268).

11 "a great solidarity, constituted by the feeling of the sacrifices that have been made and those that we are willing to make in the future. It implies a the past and it is supposed in the present by a tangible fact: the clearly expressed desire to continue living together". 
heavy internal tensions (up to a civil war, the Sonderbundskrieg, in the $19^{\text {th }}$ century) no Kanton has the intention to leave the confederation and every Swiss defines him/ herself as a Swiss citizen and part of the Swiss nation.

There is a third development to be mentioned driving to monolingualism in the $20^{\text {th }}$ century Europe, although the monolingualism is only a "side-effect" of it: ethnic cleansing and genocide. The mass murder ${ }^{12}$ or the expulsion ${ }^{13}$ of the whole population or a specific part of it improved the chances of the remaining language to become the one and only spoken and understood in this area. ${ }^{14}$

Often not only one of these three developments is responsible for the actual monolingualism of a certain society. In the case of Turkey, e.g., all three are in fact involved in carrying through the monolingualism: The Kemalistic reforms took the "republican" part (Webster 1973), the suppression of the Kurdish language among others the "imperialistic" one (McDowell, 2004, pp. 184-213), and both are completed by ethnic cleansing (as a result of the treaty of Lausanne) and genocide (of the Armenian people).

\section{One lingua franca for Europe?}

Let us now have a look on today's situation in Europe. After two devastating world wars, having experienced fascism and communism in every conceivable way, Europeans have been inclined to the principal that nations and regions can peacefully live together. Therefore, most of the European countries have decided to overcome historical boundaries and oppositions to form a European Union. Despite the fact that it is not really clear among the member states and their people how far this union has to go and what its aim is, it is obvious that the language question in the $21^{\text {th }}$ century union cannot be answered in the same way as in the $19^{\text {th }}$ or $20^{\text {th }}$ century. There is (or should I better say: there should be) no language called "European" that could be the future mother tongue of all Europeans. But this raises new questions: What is communication going to be like in a united Europe? What language should be used when the multilingual Europeans talk to each other?

I will give a little example in order to answer this question. When we travel abroad we are perhaps forced to check in at a hotel reception. In such a situation we have several options to address the reception staff:

a) We choose the language we express ourselves most comfortably in and most elegant, i.e. normally our mother tongue.

b) We choose the native language of the country we are traveling in (or the native language of the majority living in this country).

c) We choose the language which is best known on average by our possible counterparts in this country (which is not necessarily identic with the native language).

In his inspiring book "Linguistic Justice for Europe \& for the World" Philippe

12 e.g., of Armenians in Turkey during World War I (cf. Akçam, 2006 \& 2012), of Jews in the German occupied area during World War II (cf. Hilberg, 2003).

13 e.g., Greeks living in Turkey and Turks living in Greece according to the treaty of Lausanne 1923 (cf. Clark, 2006 ), Poles living in Western Ukrainia (cf. Davies, 2005, pp. 377-391) and Germans living in Poland or the ČSR (cf. Douglas, 2012) after World War II.

14 to examine the whole context of genocide and ethnic cleansing cf. Naimark, 2001, Shelton, 2005, Rosière, 2006 and Ther, 2011. 
van Parijs ${ }^{15}$ speaks about a) the egocentric criterion, b) the democratic criterion and c) the maxi-mean criterion (van Parijs, 2011, p. 14). Back to the example: We will normally think about choosing our mother tongue if and only if the reception staff wears a sign post (normally the national flag) indicating the knowledge of this language. Even in this case we will perhaps choose the native language of the visited country or the native language of the majority living in the visited country; but we only will do so, if we master this language and we are sure our counterpart does it, too. If you have ever entered an international hotel in Brussels, tried to talk French or - worse - Dutch to the reception staff, and there was a look of despair in his/her eyes, you will understand my reservation. The option $c$ ), the language which is best known on average by your possible counterparts, is no alternative either, if we do not speak it. But even if we have some knowledge of it, it may be no real alternative. You will understand at once, if you think about the following case. In Latvia or Estonia - especially if your counterpart is older than 30 years - the language which is best known on average by him/her is Russian, because either he/she is a native Russian or he/she had to learn Russian; and till today not all immigrants of the Soviet times and their descendants have mastered the native language, but all Latvians or Estonians over 30 years at a rough guess had to learn (and to speak) Russian, it would be appropriate under this criterion to address all Latvians or Estonians in every situation in Russian - ignoring the native and official languages and hoping the Latvian or Estonian counterparts, to whom the unconditional use of their native language long time threatened by Russification is part of their national identity, will understand our rational choice.

If a), b) and c) fail now, we can ask ourselves the following question: "Which language is best known by the member of your audience who knows it at least well?" (dito.) If we can answer this question, we may also have the answer to the question, what should the lingua franca of this social community be, the language people of different mother tongues normally use, if there is no other preference for another language by, e.g., mastering the mother tongue of one partner in the communication by all the others. In most parts of Europe the answer to the question quoted above will currently be "English". "The current role of English in Europe is thus characterized by the fact that the language has become a lingua franca, a language of wider communication, and has entered the continent in two directions as it were top-down by fulfilling functions in various professional domains and, simultaneously, bottom-up by being encountered and used by speakers from all levels of society in practically all walks of life" (Seidelhofer/Breideneder/Pitzl 2006, p. 5). It is clear that the fact that the most likely lingua franca in Europe "is English has nothing to do with any intrinsic superiority it might have possessed. However, as no other natural language can plausibly claim such superiority, there is no good reason to take on the daunting task of undoing the huge advantage achieved by English" (van Parijs 2011 , p. 37). For many authors this is especially true for the language use within the institutions of the EU and the communication between the EU administration and its

15 Although I contest van Parijs argumentation in a very fundamental way, I am far from neglecting that his book has been the most valuable contribution to this subject up to now; in fact he has really opened the discussion beyond the limits of applied linguistics with his paper published in Politics, Philosophy and Economics (van Parijs, 2002). It should be also clear that I cannot do full justice to his profound argumentation in a short paper like this. 
citizens. They want to reverse the commitment to multilingualism (20 official and 3 working languages) and concentrate on English as the lingua franca. Resuming an overview of this discussion, Buchmüller-Condoni gives three main points in favour of English as lingua franca (ELF):

a) ELF would create more fairness and effectiveness in the inner-European processes.

b) ELF would protect the EU from being an exclusively elitist project.

c) ELF helps to form a common European identity (Buchmüller-Condoni 2012, p. 3).

This matches with the mainstream argument of English native academics. If they utter a criticism to ELF, they do not criticize ELF from a pragmatic view: "ELF is seen as non-controversial and is taken for granted by many professionals working internationally"; the negative responses are "coming primarily from within the field of English studies" and are concerning the nature of ELF (Jenkins 2009, p. 202).

Having granted that a lingua franca is useful in a multilingual Europe, perhaps we should not rush into asserting that we need only one. In my view, there are three possible ways of understanding a lingua franca pluralism:

a) A disjunctive interpretation of lingua franca pluralism which "consists in viewing one or more lingua francas as substitutes for each other; each person is expected to learn only one of them." (van Parijs 2011, p. 46).

b) A conjunctive interpretation of lingua franca pluralism which "consists in viewing the two or more languages granted lingua franca status not as substitutes but as complements" (ibid., p. 47). Each person is expected to learn all of them; in most versions of this interpretation a person has to acquire active knowledge of only one language and passive knowledge of the others.

c) An additive interpretation of lingua franca pluralism consists in viewing one lingua franca as basic and other languages as additional used in specific contexts, e.g., English as the basic lingua franca and French in the postal services, Italian in music, German in construction business, etc.

All interpretations of lingua franca pluralism are made under the condition that there are political decisions in favour of it. Despite these political decisions the "natural" power of English will carry through.

Let us assume that lingua franca pluralism is desirable, what kind of lingua franca pluralism should it be? In the disjunctive interpretation, the number of these people able to talk to each other decreases in proportion to the increase of the number of the people and the number of languages in this group. Therefore, this kind of lingua franca pluralism does not achieve its purpose. The biggest problem of the conjunctive interpretation is the answer to the question, which languages should get the status as lingua franca. In the end, all European languages will have to be granted this status. Therefore, also this kind of lingua franca pluralism will not achieve its purpose. These two versions of lingua franca pluralism are on van Parijs' agenda, too; the third interpretation is not. That is because he - equally as the French revolutionaries of $1789 \mathrm{ff}$. preferring one national language and most applied linguists accepting ELF for granted - is in favour of one lingua franca, English, for the sake of egalitarian justice putting the other languages at stake. He concedes that "it is unfair that non-Anglophones should shoulder the whole burden of learning the lingua franca. But the extent of this unfairness will shrink as a consequence of the 
spreading of this lingua franca" (van Parijs 2011, p. 208). He measures unfairness only in the currency of mastering the language on a specific level, because the extent of the advantage of the Anglophones "is bound to shrink, even be reversed, as the lingua franca keeps spreading more widely and more deeply" (ibid.). Therefore, he fails to notice that an additive interpretation of lingua franca pluralism avoids the negative consequences of the preceding. In this interpretation, everybody has at least basic skills in one common language; accepting the realities, this is English. But by political (!) decision, special defined sectors of the European universe should be forced to use a certain lingua franca. This seems possible, because the development towards the dominant monolingualism in the era of nation-states was an expression of the political will at that time, and a new political will may diminish the "natural power" of the English language in favour of a greater range of possible linguae francae.

Take the postal services as an example: For historical reasons - because in 1874, its founding year, the main diplomatic language was French - the Union Postale Universelle decided as a result of the Traité concernant la création d'une Union générale des postes on French as the international postal language, and this decision is still working. You write "(envoi) recommandé" on your international letter for the recorded delivery, you can use the French name of a country to write the address in a foreign country, e.g., "Pays-bas" for the Netherlands, and so on. Why should not all communication between postal services in the European countries take place in French? That would mean: French is the lingua franca for the postal services. But notice again: You have to make a political decision and force the postal services to communicate in French.

\section{Linguistic justice}

In the additive interpretation of lingua franca pluralism we accept the reality that English is widely spoken among the Europeans, but give other languages a fair chance to continue to exist beneath this predominant lingua franca not only as regional and family dialects. But that is only the first step to an issue called "linguistic justice".

Linguistic justice is said to be necessary, because

a) the speakers of the lingua franca as a mother tongue have a natural and not acquired, an involuntary advantage to those who have to learn it as a foreign language; this advantage is not only linguistic; it has its consequences in the economic, political, etc. achievements of the speaker;

a) the terms of the lingua franca determine more than a verbal sense; they determine a way of interpretation by the tradition of the terms in this language.

It is clear that you have to learn more and spend a lote of time to speak fluent English; that disadvantages you in case of a business career with regard to an English native. Referring to a), does it really have the consequence of sharing the burden between the native speakers and the second-language speakers of the lingua franca, and is this owed to linguistic justice? The egalitarian approach ${ }^{16}$ of van

16 Egalitarianism is a kind of social philosophy advocating the elimination of involuntary disadvantage caused by inequalities among people via redistribution of goods or decentralisation of power; main representatives are G.A. Cohen, R. Dworkin, Ph. Van Parijs, J. Rawls, A. Sen. 
Parijs insinuates that we have, e.g., to tax "countries, that is politically organized communities, in proportion to the number of English native speakers they house" (van Parijs, 2011, p. 76) in favour of the non-native speakers. To be treated as an equal does not - even from the egalitarian point of view - involve the right "to receive the same distribution of some burden or benefit, but to be treated with the same respect and concern as anyone else. ... Individuals may have the right to individual treatment in elementary education, because someone who is denied elementary education is unlikely to lead a useful life" (Dworkin, 1978, p. 227). But speaking the lingua franca on the same level as a native speaker is not so vital that everyone should have an equal right to it, and when that right cannot be kept, a reverse discrimination of non-native speakers of the lingua franca has to be brought into force. The only founding principal of this special reverse discrimination is then envy; the non-native speaker is envious of the native speaker's advantages and prefers that he (i.e. the native speaker) shall not have them either. Following Robert Nozick, it appears obvious to me "that if people feel inferior because they do poorly along some dimensions, then if these dimensions are downgraded in importance or if scores along them are equalized, people no longer will feel inferior. ... But it may well be that other dimensions would replace the ones eliminated with the same effects (on different persons)" (Nozick, 1974, p. 243). Instead of giving the individual the right of equal access to a specific linguistic level and compensating him/her in the case to be expected that he/she cannot achieve the promised level of mastering the lingua franca, it would be better to develop a lingua franca pluralism to guarantee the linguistic justice.

To understand b) I will give another example: the term "letter of intent" is widely used concerning negotiations of contracts of different natures. In German it is normally translated as "Absichtserklärung". This verbal translation is extremely misleading. If you sign a "letter of intent", you are normally obliged to do as you signed; it is a kind of formal obligation; there is no return. The term has a specific juridical tradition. The German "Absichtserklärung" is informal and of no obligation; at any time, you can drop your plans; you always have a way out. This is the consequence of another juridical tradition. If you use the lingua franca, you also accept its traditions and dismiss the others. For both reasons it seems to be a question of justice to use not only one language as lingua franca but to spread the disadvantages of the use of a lingua franca among all European citizens and traditions.

But it is not enough to spread the disadvantages of the use of a lingua franca. Justice means primarily not to compensate involuntary disadvantages, in this case the bad brute luck of the people not speaking English as their mother tongue. It means first to give everybody the respect due to him/her despite his/her natural advantages or disadvantages. That is the duty of a decent society. The claim involves "the right to treatment as an equal, not to receive the same distribution of some burden or benefit, but to be treated with the same respect and concern as anyone else" (Dworkin 1978, p. 227). If language is one of the core concepts of a person, every person has in general the right to be addressed in his mother tongue. Van Parijs is accepting this in his "linguistic territorial principal" (van Parijs, 2011, pp. 133-174), too. Native speakers of minority languages should gain the right to give their language the status of an official language for official use (admin- 
istration, education, etc.), if this minority language is spoken by a relevant part of inhabitants of a certain territory. Van Parijs is convinced that this right fulfills the requirements of the linguistic justice completely. But he overlooks the fact that the bulk of language use is private conversation. Treating people with respect requires more than giving them the right to use their native language at school etc., it means "dealing with them exclusively on the basis of those aspects of their particular character or circumstances that are actually relevant to the issue at hand" (Frankfurt 1987, p. 10), in our case the language of the private and every day conversation. While the right to use the mother tongue can be formalized in the official context (at the bar, town hall, etc.), and often the claim for the use of the mother tongue in the official life is the main claim in gaining minority rights, it is not so "easy" in private life. Particularly, in a multilingual Europe it is not realistic that every alien counterpart in a conversation should have the knowledge of your native language. Remember, that was yet the reason why the disjunctive multilingualism has failed before. So we have to be more modest. (European) politics has the task to provide people with the most possible knowledge of foreign languages to give them really the possibility to address the most possible number of people in their native language to give them the respect due to them.

But the respect due to the people of a multilingual Europe requires a second thing. In the European Union there are official languages having from 95 million native speakers (German) to 350000 native speakers (Maltese). Especially the minor languages are threatened to be pushed back to family use, because even in an additive interpretation of lingua franca pluralism there is no real chance for Maltese, Slovenian or Estonian, not to mention the minority languages as Sorbian, Frisian, Sami, Romansh, etc., to become a partial lingua franca getting more secondary and official speakers. The respect for Estonians, Maltese, Slovenians, etc. forces the European politics to build up an institutional framework to increase the number of secondary speakers of these languages. That gives more people the chance to give these people of minor languages the respect due to them by addressing them in their native language, too. And the minor languages will have a better chance to survive as languages in the full sense, i.e. languages that can be used in all sectors of the common life, not only in the family. Since a language has to be used not to atrophy, it is necessary to widen the possible speaking occasions and the objects you will talk about in this language. The best way to do this is to widen the community of the possible speakers of this language that people with different mother tongues may more often and in more different situations switch to one speaker's mother tongue, even if it is a minor language. An egalitarian approach would perhaps compensate the native speakers of a minor language for the bad brute luck speaking a language not widely used on the continent accepting the disappearance of the minor languages off many parts of the social life even in the home countries of these languages. Compensation of using a minor language as a mother tongue, however, claims a stigma and the innate inferiority of the minor languages' native speakers having - unwillingly - not acquired a "real" language as a mother tongue. Widening the community of speakers does quite the reverse. It underlines the principal and fundamental equality of every language, and leaves its speakers without any stigma. 
The stigma is an effect of the congenital defect of each egalitarian approach, the lack of respect of the real human beings concerned, in this case the native speakers of minor languages. The egalitarian "defines the deserving disadvantaged in terms of their innate inferiority of talent, intelligence, ability, or social appeal" (Anderson, 1999, p. 311). Van Parijs "linguistic territorial principal" grants "each linguistic community the right to impose its language as the medium of instruction and public communication in some territory" (van Parijs, 2011, p. 208) and can have the effect to secure a certain level of linguistic diversity. Van Parijs emphasizes, however: "This must not be its purpose, and cannot be its justification" (ibid.). His position is justified if and only if you take into account nothing else than the linguistic community while making allowances for the "innate" inferiority of the individual speakers of the (minor) languages. Unlike him, I propose to start with the individual speakers, to neglect their "innate" inferiority caused by their mother tongue, and to give them the respect due to them by widening the community of speakers of the respective languages.

\section{Conclusions}

Communication is the core of modern society. In a multilingual Europe the need for inter-national communication is confronted with the two-century long tradition of proposing one national language as one of the founding principals of the national state and the resulting monolingualism. To overcome the speechlessness in a multilingual environment the first way seems to establish a lingua franca parallel to the implementation of a national language in the national state. De facto English has become this status today (not only in the EU, but in many parts of the world). ELF seems to be unquestionable. This development has created a new monolingualism in "inter-national" discourse with a new "inter-national" language and is heavily discussed in linguistics (Jenkins, 2009). But this development is not justified under the aspect of linguistic justice. At least in the EU the necessity of inter-national communication via a lingua franca can be combined with a multilingual approach: a lingua franca pluralism in an additive interpretation. This will be a first step to linguistic justice which is as important as social or political justice, if we concentrate on the real people, their well-being and wishes. The second step to linguistic justice reflects the importance of the mother tongue for self-esteem. Only a sustainable multilingualism gives speakers of all languages the respect due to them by the spreading of competence in as many languages as possible among the Europeans. But the proposed substantial multilingualism is sustainable, if and only if

a) a normal European citizen has learned more than one foreign language;

b) a normal European citizen has the chance, accepts the necessity, and feels the obligation to use different foreign languages in his/her everyday life; this is guaranteed in official use and professional life, e.g., by an additive lingua franca pluralism;

c) a normal European citizen develops sensibility and respect for all other European citizens accepting them as persons, that means: "Handle so, daß du die Menschheit, sowohl in deiner Person als in der Person eines jeden anderen, 
jederzeit zugleich als Zweck, niemals bloß als Mittel brauchest"17 (Kant 2007, p. 66). Doing so a European citizen is inter alia eager to address another European citizen in his/her mother tongue and to take part in securing the use and usability of minor languages.

Therefore, I will end with adding two demands (to whom it may concern):

a) The demand for an obligation to teach at least three foreign languages to every pupil at every school; one of these languages should be English and one of these languages should be a minor European language (Estonian, Irish, Latvian, Lithuanian, Slovenian, etc.). The learning of English may begin in the $3^{\text {rd }}$ form, of the second foreign language in the $5^{\text {th }}$, and the learning of the third should begin in the $7^{\text {th }}$ form. This order would guarantee every pupil the possibility to learn a foreign language for at least three years probably ending at least at the level B1/ B2 according to the Common European Framework of Reference for Languages: Learning, Teaching, Assessment.

b) The demand for an obligation to teach at least some subjects at every school in a foreign language and this foreign language should not be exclusively English.

\section{References}

Akçam, T. (2006). A shameful act: The Armenian genocide and the question of Turkish responsibility. New York: Metropolitan Books.

Akçam, T. (2012). The Young Turks' crime against humanity: The Armenian genocide and ethnic cleansing in the Ottoman Empire. Human rights and crimes against humanity. Princeton, N. J: Princeton University Press.

Anderson, E. S. (1999). What is the Point of Equality. Ethics, 109, 297-337.

Bochmann, K., Brumme, J., \& Guespin, L. (1993). Sprachpolitik in der Romania: Zur Geschichte sprachpolitischen Denkens und Handelns von der Französischen Revolution bis zur Gegenwart. Berlin, New York: De Gruyter.

Braunmüller, K., \& Ferraresi, G. (Eds.). (2003). Aspects of multilingualism in European language history. Amsterdam, Philadelphia, PA: J. Benjamins Pub.

Buchmüller-Condoni, C. (2012). Democracy and linguitic justice in the European Union. Living Reviews in Democray, 1-16. Retrieved from www.livingreviews.org/lrd-2012-1.

Certeau, Michel de/ Julia, Dominique/ Revel, Jacques. (1974). Une politique de la langue: La révolution française et les patois. Paris: Gallimard.

Clark, B. (2006). Twice a stranger: How mass expulsions that forged modern Greece and Turkey. Cambridge, Mass: Harvard University Press.

Commission of the European Communities. (2005). Communication from the Commission to the Council, the European Parliament, the European Economic and Social Committee and the Committee of the Regions: A New Framework Strategy for Multilingualism. Retrieved from http://eur-lex.europa.eu/LexUriServ/LexUriServ.do?uri=COM:2005:0596:FIN:EN:PDF.

Commission of the European Communities. (2008). Communication from the Commission to the Council, the European Parliament, the Council, the European Economic and Social Committee and the Committee of the Regions: Multilingualism: an asset for Europe and a shared commitment. Retrieved from: http://eur-lex.europa.eu/LexUriServ/LexUriServ. do?uri=COM:2008:0566:FIN:EN: PDF.

Davies, N. (2005). God's playground: A history of Poland. Vol. 2 (Rev. ed). New York: Columbia University Press.

17 "Act in such a way that you treat humanity, whether in your own person or in the person of any other, never merely as a means to an end, but always at the same time as an end." (translated by James W. Ellington, 1993, p. 43). 
Douglas, R. M. (2012). Orderly and humane: The expulsion of the Germans after the Second World War. New Haven [Conn.]: Yale University Press.

Dworkin, R. (1978). Taking rights seriously. Cambridge: Harvard University Press.

Frankfurt, H. (1997). Equality and Respect. Social Research, 64, 3-15.

Gasimov, Z. (Ed.). (2012). Kampf um Wort und Schrift: Russifizierung in Osteuropa im 19.-20. Jahrhundert. Göttingen: Vandenhoeck \& Ruprecht.

Ginsburgh, V. (2005). Disenfranchisement In Linguistically Diverse Societies: The Case Of The European Union. Journal of the European Economic Association, 3(4), 946-965.

Gosseries, A., Vanderborght, Y., \& van Parijs, P. (eds.). (2011). Arguing about justice: Essays for Philippe Van Parijs. Louvain: Presses Universitaires de Louvain.

Hilberg, R. (2003). The destruction of the European Jews (3 ed). New Haven, London: Yale Univ. Press.

Hüning, M., Vogl, U., \& Moliner, O. (Eds.). (2012). Standard languages and multilingualism in European history. Amsterdam, Philadelphia: John Benjamins Pub. Co.

Jenkins, J. (2009): English as lingua franca: interpretations and attitudes. World English 28, 200207

Kant, I. (2007) Grundlegung zur Metaphysik der Sitten. Edited by Horn, C. et alii. Frankfurt am Main: Suhrkamp (English translation by James W. Ellington (1993). Grounding for the Metaphysics of Morals 3rd ed. Hackett).

Lönz, M. (2012). Getrennt marschieren, vereint schlagen? Über Identität und Differenz als Europäische Leitmotive. Sustainable Multilingualism, 1 (1), 43-53. DOI 10.7220/2335-2027.1.5.

Luckyj, George Stephen Nestor. (1990). Literary politics in the Soviet Ukraine, 1917-1934 (Rev. and updated ed). Durham: Duke University Press.

Lüdi, G. (2011). Neue Herausforderungen an eine Migrationslinguistik im Zeichen der Globalisierung. T. Stehl (ed.), Sprachen in mobilisierten Kulturen. Aspekte der Migrationslinguistik. [Potsdam]: Universitätsverlag Potsdam, 15-38.

Lüdi, G. (2012). Traces of monolingual and plurilingual ideologies in the history of language policies in France. M. Hüning, U. Vogl \& O. Moliner (eds.). Standard languages and multilingualism in European history. Amsterdam, Philadelphia: John Benjamins Pub. Co, 205-230.

Magocsi, P. R. (1996). A history of Ukraine. Toronto [u.a.]: University of Toronto Press.

McDowall, D. (2004). A modern history of the Kurds (3rd rev. and updated ed). London, New York: I.B. Tauris.

Mertelsmann, O. (Ed.). (2012). Everyday life in Stalinist Estonia. Frankfurt am Main, New York: Peter Lang.

Mertelsmann, O. (2012). What is Sovietization? O. Mertelsmann (ed.). Everyday life in Stalinist Estonia. Frankfurt am Main, New York: Peter Lang, 9-25.

Miller, A. I. (2003). The Ukrainian Question. The Russian Empire and Nationalism in the Nineteenth Century. Budapest, New York: Central European University Press.

Naimark, N. M. (2002). Fires of hatred: Ethnic cleansing in twentieth-century Europe (1st Harvard University Press paperback ed). Cambridge, Mass: Harvard University Press.

Nozick, R. (1974). Anarchy, State, and Utopia. Oxford: Basil Blackwell Ltd.

Ohnheiser, I. (1999). Sprachen in Europa: Sprachsituation und Sprachpolitik in europäischen Ländern. Innsbruck: Inst. für Sprachwiss.

Renan, E. (1882). Qu'est-ce qu'une nation? Paris: Calmann Lévy.

Rosière, S. (2006). Le nettoyage ethnique: Terreur et peuplement. Carrefours. Les dossiers. Paris: Ellipses. 
Seidelhofer, B., Breiteneder, A., Pitzl, M.-L. (2006). English as a Lingua Franca in Europe: Challenges for applied linguistics. Annual Review of Applied Linguistics 26, 3-34.

Shelton, D. (2005). Encyclopedia of genocide and crimes against humanity. Detroit: Macmillan Reference.

Smith, M. G. (2012). The Hegemony of Content: Russian as the Language of State Assimilation in the USSR, 1917-1953. Z. Gasimov (ed.). Kampf um Wort und Schrift. Russifizierung in Osteuropa im 19.-20. Jahrhundert. Göttingen: Vandenhoeck \& Ruprecht, 193-208.

Stehl, T. (Ed.). (2011). Sprachen in mobilisierten Kulturen: Aspekte der Migrationslinguistik. [Potsdam]: Universitätsverlag Potsdam.

Tandefelt, M. (2003). Vyborg. Free trade in four languages. K. Braunmüller \& G. Ferraresi (eds.). Aspects of multilingualism in European language history. Amsterdam, Philadelphia, PA: J. Benjamins Pub., 86-104.

Ther, P. (2011). Die dunkle Seite der Nationalstaaten: "Ethnische Säuberungen" im modernen Europa. Göttingen: Vandenhoeck \& Ruprecht.

van Els, Th. (2005). Multilingualism in the European Union. International Journal of Applied Linhuistics 15 (3), 263-281.

van Parijs, P. (2002). Linguistic Justice. Politics, Philosophy and Economics, (1), 59-74.

van Parijs, P. (2011). Linguistic justice for Europe and for the world. Oxford, New York: Oxford University Press.

Webster, D. E. (1973). The Turkey of Atatürk: Social process in the Turkish reformation. New York: AMS Press.

\section{Michael Lönz}

Rūro universitetas, Bochumas, Vokietija; MichaelLoenz@aol.com

\section{VIENYBĖ IVAIROVE்JE. DAUGIAKALBYSTĖS POREIKIS VIENINGOJE EUROPOJE}

Santrauka. Suprasti Europa - tai suvokti kultūros, politikos ir kalbos ivairovę. Daugiakalbeje Europoje daugiakalbystès principui grèsmę kelia akivaizdus anglu kalbos dominavimas. Dèl šios priežasties Europos Komisija iškèlè "kalbinès ivairovès" ideja. Šiame straipsnyje aptariama šio termino esmè. Pirmiausia reikia pasakyti, kad vienkalbystès principas atsirado tiktai formuojantis tautinei valstybei XIX-XX a. Tuo metu lingua franca statusas buvo plačiai svarstomas moderniajame pasaulyje, ypač to meto Europoje, siekiant apginti požiūri, kad kultūringa visuomenè privalo užtikrinti ne tik socialini bei politini, bet ir kalbini teisinguma remdamasi daugiakalbystès principu. Daugiakalbystès ideja suteikia galimybe net mažoms kalboms, kad ju kalbos būtu vartojamos platesniu aspektu. Straipsnio pabaigoje pateikiami du daugiakalbystès plètojimo reikalavimai: kiekvienas mokinys kiekvienoje mokykloje būtinai turi mokytis mažiausiai tris kalbas ir kad bent keletas dalyku kiekvienoje mokykloje būtu dèstomi užsienio kalba, nebūtinai ši užsienio kalba turètu būti anglu kalba.

Pagrindinès sąvokos: kalbinè ivairovè, kalbinis teisingumas, daugiakalbystè, lingua franca, mažosios kalbos. 